\title{
Employment Exits Near Retirement Age: An Agency-analysis
}

\section{Hanna Kosonen}

Doctoral Researcher, Faculty of Social Sciences, Tampere University, Finland

I Katri Keskinen

Doctoral Researcher, Faculty of Social Sciences, Tampere University, Finland

\section{Pirjo Nikander}

Research Director, Tampere University, Finland

\section{Kirsi Lumme-Sandt}

University Lecturer, Faculty of Social Sciences, Tampere University, Finland

\begin{abstract}
Population aging has prompted international governing bodies to recommend extending work careers and postponing retirement age. Retirement decisions cannot be fully reduced to either structural influences or individual agency. Older workers may face several limiting factors when continuing their careers beyond the official retirement age, including internalized attitudes towards aging at work. Our aim is to develop agency analysis that involves both structural and individual components to fully illustrate the heterogeneity of older workers and their retirement decisions. By studying qualitative interview data via thematic content analysis and a modality-based agency framework, we found that agency manifests in various different ways in older employees' work exit accounts and that the relationship between individual agency and structures is complex. We conclude that agency analysis of aging employees offers insights into the complexity of the retirement process and may thus inform us about how to help extend work careers.
\end{abstract}

\section{KEYWORDS}

Agency / aging workers / heterogeneity / modality-based agency model / retirement

\section{Introduction}

he challenges of population aging in post-industrial Western countries have led the EU and the OECD, among others, to recommend extended work-lives and a postponed retirement age (OECD 2006; Eurofound 2019). Retirement decisions are dependent not only on the individual employee but also on several structural factors, such as official retirement age and organizational and governmental age policies (Pärnänen 2012; Vickerstaff 2006). Also influential are the attitudes employers and employees alike may hold concerning a standard retirement age (Pärnänen 2012). These structures and attitudes influence one another in a bi-directional way (ibid.).

\footnotetext{
${ }^{1}$ You can find this text and its DOI at https://tidsskrift.dk/njwls/index.

${ }^{2}$ Corresponding author: H. Kosonen, E-mail: hanna.kosonen@tuni.fi.
} 
Vickerstaff (2006) attributes a large share of retirement decisions to managers and questions the responsibility increasingly placed upon individual aging employees, noting that even 'voluntary redundancy and early retirement' can 'mask considerable organizational impact' (ibid., p. 458). However, the reigning agenda to extend working careers has shifted more responsibility to individuals as career decision-makers (Krekula \& Vickerstaff 2019), as retirement as we know it has become more and more blurred (Gilleard \& Higgs 2000). As individuals are given more responsibility to make decisions about their careers, the volition of these career choices comes into question.

Agency is conceptualized in previous studies as the degree to which we can attribute what we do to ourselves as opposed to societal structures, which may enable or limit our actions (see, e.g., Higgs et al. 2003). Previous studies have looked at the role of, for example, education level and physical health (Solem et al. 2016), norms, and values (Berglund et al. 2017), job satisfaction, job control, organizational practices, and financial incentives (van Oorschot \& Jensen 2009) on either retirement outcomes or decisions. They have, in turns, found all of these to be contributing factors in some way.

Solem et al. (2016) found a significant correlation between limited labor market resources (low education level and impaired health) and a limited ability to implement preferences regarding late retirement among older Norwegian workers. However, they also found '.. . that the likelihood of earlier than preferred retirement increased as the preferred retirement age increased to a larger extent for white-collar workers and workers in good health compared to blue-collar workers and workers in poor health' (Solem et al. 2016, p. 277).

Krekula (2019), in turn, implied that there are age-related norms that assumed work transitions to be more feasible at younger ages among 56 to 74-year-old Swedish men in heavy manual labor and managerial positions. The manual laborers demonstrated a willingness to transition to less physical work at older ages, and they were indeed expected to plan for just such contingencies, but there was no organizational structure in place to facilitate internal work transitions. Their employer no longer readily provided support for these changes based on economic rationale (Krekula 2019).

Berglund et al. (2017) emphasize the role of norms and values in retirement outcomes in their study on prolonged employment after pension eligibility in Sweden and conclude the following: 'The norm to quit, which is emphasized by the institutionalized pension system, and the values and preferences connected to life as a pensioner, are strong social forces that condition employees' retirement decisions' (ibid., p. 33). Interestingly, their study took place at a time when pension reforms that specifically intended to retain older employees had been recently introduced.

The various contributing factors studied in previous Nordic literature on retirement do not fully explain the variability in retirement decisions. Berglund et al. (2017) found that work ability decreased in its ability to predict retirement outcomes as older employees got closer to the age of 67 years, and that financial incentives to keep working may have actually been counteracted by norms and values. Hermansen and Midtsundstad (2018) found that financial incentives also have limited ability in accounting for Norwegian retirement behavior.

In our view, Jyrki Jyrkämä's (2008) model enables the simultaneous study of all of the aspects discussed above: work ability and the various other push and pull factors, as well as their interactions. In this paper, we therefore suggest that studying these aspects together using a multifactorial model can substantially contribute to both theoretical 
discussions and empirical work in the field, and that Jyrkämä's theoretical framework functions as a practical and promising starting point for this work.

From the field of aging research, Tulle (2004) and Jyrkämä (2008) present studying agency among older people as a potential tool to help question and dismantle limiting stereotypes about aging. Much of the discussion concerning aging individuals focuses on a decline in their capabilities (Tulle 2004). These ageist ideas manifested within societies are then reinforced by institutions that reproduce an ageist ideology (e.g., Bytheway 2005), enforcing negative conceptualizations of aging that often limit the agency of aging individuals (Bytheway 2005; Tulle 2004). It is therefore important to study their agency in the context of work in order to enable older employees to break free from limiting, predetermined positions and identities. Higgs et al. (2003) explicitly make a case for studying the interplay of structural factors and individual agency in early retirement (p. 764).

In this paper, we investigate older employees' agency in work exit situations after dismissals or resignations. Our main goal is to contribute to the theoretical and empirical work on agency, and to test the viability of Jyrki Jyrkämä's (2008) agency model as a potential tool for identifying how various factors and dimensions of agency come together in individual cases in relation to the work exit situation near retirement age.

In what follows, we first introduce our theoretical framework for investigating older employees' agency, by applying Jyrkämä's (2008) theoretical model of agency in old age. Second, using interview data from former postal service employees, we test the viability of this theoretical model. Finally, we consider whether this model could be used to understand older employees' work exit decisions and how such an analysis might inform us about aging employees.

Our research question is:

'How do the dynamics between agency and structure manifest in long-term employment exit situations near retirement age as narrated by aging employees?'

\section{Theory}

Jyrki Jyrkämä's (2008) model of modality-based agency is rooted in Anthony Giddens' structuration theory, as well as the social semiotics and semiotics traditions, most notably the works of Algirdas Greimas and the associated Paris School. Giddens' structuration theory proposes a two-way relationship between agency and structure where structures both influence individual autonomy and are recreated in individuals' use of agency, that is, '... the structural properties of social systems are both medium and outcome of the practices they recursively organize' (Giddens 1984, p. 25).

Jyrkämä utilizes Giddens' concept of agency as the interplay of societal structures and the individual. He then approaches agency as a combination of six modalities or dimensions that fit structural factors and the individual actor together in a situationally forming dynamic that is agency. For this purpose, Jyrkämä borrows four modalities included in the Paris School's semiotic model: 'wanting, knowing, having-to, and beingable-to', adding the modalities Feel and Can in place of the more traditional 'being' and 'doing' (Jyrkämä 2008, p. 195; Perron et al. 1989, p. 112). 
To our knowledge, Jyrkämä's (2008) model is yet to be utilized on a data-set involving work exit or retirement situations, and different modality combinations in a situation have not yet been analyzed by previous studies. Our goal is to see how the model might be utilized to study work exit situations near retirement and how such an analysis might inform us about aging employees. The agency analysis is based on identifying six modalities of agency in participants' speech (Finnish originals in brackets): Be Able (kyetä), Must (täytyä), Can (voida), Feel (tuntea), Want (haluta), and Know-How (osata), explained in more detail in Table 1. Presented in the table are our translations of the original outlines of the six modalities by Jyrkämä (2008) and our operative definitions based upon them.

Jyrkämä (2008) notes that without context, his theoretical framework remains at an abstract level; we exemplify these modalities in practice with a hypothetical example of Juha, 62, who has recently been dismissed from his workplace. Juha needed to vacate his workplace due to global downsizing. Now, he faces a decision to retire or not to retire.

First Juha considers his health; he considers himself able enough to keep working despite some chronic problems with his joints. He would still like to enjoy his retirement days without having health issues, so if he decides to look for a job, it cannot risk his health in any way. Then, he considers musts. Juha knows that a lengthy unemployment

Table I Jyrkämä's (2008) six modalities of agency (after Kosonen \& Keskinen 20 I9, p. 37)

\section{Modalities Description by Jyrkämä(2008, p. 195) Operative definition of agency}

\begin{tabular}{|c|c|c|}
\hline Be Able & $\begin{array}{l}\text { '... is primarily about physical and } \\
\text { psychological abilities and being-able-to's: } \\
\text { in this sense, it is possible to speak of the } \\
\text { traditionally understood capability which } \\
\text { varies from situation to situation and where } \\
\text { changes take place during aging.' }\end{array}$ & $\begin{array}{l}\text { Reports of coping, or lack thereof, and } \\
\text { physical or psychological ailments affect- } \\
\text { ing one's ability to work and/or live } \\
\text { one's life. }\end{array}$ \\
\hline Must & $\begin{array}{l}\text { '... includes physical as well as social - } \\
\text { normative and moral - hindrances, musts } \\
\text { and limitations.' }\end{array}$ & Internal and external 'musts'. \\
\hline Can & $\begin{array}{l}\text { '... refers to the opportunities which each } \\
\text { situation and the various structures and } \\
\text { factors therein produce and enable.' }\end{array}$ & $\begin{array}{l}\text { Reports of situational opportunities } \\
\text { and enabling factors related to them. } \\
\text { We also included reports of the partici- } \\
\text { pants' actual or hypothetical decisions in } \\
\text { this modality. }\end{array}$ \\
\hline Feel & $\begin{array}{l}\text { '... is connected to the basic human } \\
\text { [tendency to] consider, evaluate, experience } \\
\text { and connect his/her feelings to situations and } \\
\text { things encountered.' }\end{array}$ & $\begin{array}{l}\text { Situational assessments, reports of } \\
\text { emotions, and value-judgments. }\end{array}$ \\
\hline Want & $\begin{array}{l}\text { '... has to do with motivation }[\ldots] \text {, } \\
\text { wanting, goals and objectives.' }\end{array}$ & $\begin{array}{l}\text { Reports of what one wants now and } \\
\text { what one wanted or would have wanted } \\
\text { or liked in a past situation. }\end{array}$ \\
\hline Know-How & $\begin{array}{l}\text { '... very broadly refers to knowledge and } \\
\text { skills, various types of permanent Know- } \\
\text { How, which a person has accumulated for } \\
\text { him/herself during his/her life course, or will } \\
\text { be acquiring.' }\end{array}$ & $\begin{array}{l}\text { Reports on the brevity of a participant's } \\
\text { work experience and of their skill-set } \\
\text { and strengths, and schooling undertaken } \\
\text { during or after career. }\end{array}$ \\
\hline
\end{tabular}


period before retirement is likely to reduce his pension, and that the government wants people to extend their careers in old age. However, he is also a fitting age for an early exit scheme to retirement on offer to those with a 40-year work career. He then considers what he can do. Juha has a large social network and could ask around for a job, as some of his friends have done. He also considers going back to school and learning a new language or finishing the college degree that was left unfinished some 40+ years ago. He then considers how he feels. He values work greatly, but at the same time, he feels that he has already earned his retirement through his impressively lengthy career. At this point, he does not know what he wants, nor does he have the motivation to learn a new profession or start an intensive job search. Having worked some 40 years in the same profession, Juha has strong know-how of his previous job-related tasks. However, it has been a couple of decades since he last applied for a job, something he now finds himself unable (due to lack of know-how) to do.

The various modalities and their coordinates in a situation, such as the person's age, gender, cohort, time period, social class, and cultural background, impact one another and dynamically form each person's situational agency (Jyrkämä 2008). Two people in the same situation, thus, do not necessarily share the same components of agency in their perception of that agency. Jyrkämä's agency model reconciles structures and agency by theorizing the six modalities as a situational dynamic where the modalities Can and Must entail structural factors not dependent upon the individual (Jyrkämä 2008, p. 195).

In terms of our study context, the modalities Can and Must carry with them such limiting or enabling social structures as retirement legislation, the pension system, local employment opportunities, and organizational practices concerning older employees. They also contain such external actors as the older employees' friends, coworkers, familymembers, or even younger employees, whom they do not necessarily know personally.

In what follows, the structure-bearing modalities Can (opportunities and decisions) and Must (imperatives and limitations, particularly of the moral and normative variety in this context) shall be compared according to their relationships to the other four modalities: Be Able (physical and mental capabilities), Feel (emotions, situational assessments, moral judgments), Want (desires, motivations and goals), Know-How (accumulated expertise and education).

\section{Method}

Our study focuses on former older employees of Finland's state-owned postal service company, currently named Posti Group (henceforth: Posti), and the various routes these individuals have taken to retirement following large-scale dismissals. In what follows, we will present our research context, provide pertinent data on our participants, and finally, describe our data gathering process and analytical approach. To preserve anonymity, all participants in our study are referred to by assigned code number and/or pseudonym; their exact ages and hometowns are not disclosed, nor are their work units within Posti identified.

\section{Research Context}

Unlike in most Western countries, larger decisions on dismissals in the Nordic countries are made based on collective agreements and cooperative negotiations (Jolkkonen 
et al. 2012). The potential income losses in these decisions are partly compensated by the welfare state (ibid.) or, in Posti's case, a severance package that secured wages up to six months after the end of employment. In Finland, for people born in 1954 or earlier, 63 years is the official retirement age; this gradually increases up to 65 years, which is the official retirement age for people born in 1962-1964 (Finnish Centre for Pensions 2019a). Our participants fall into these age categories.

Additionally, people experiencing unemployment near retirement age, if they desire, may exit working life earlier. The Finnish unemployment pathway to retirement secures unemployed older people financially for up to 500 days, provided that they have worked at least five of the past 20 years, allowing them to move from unemployment to retirement smoothly at age 60 and over, depending on their year of birth (Finnish Centre for Pensions 2019b).

The unemployment pathway to retirement was established in the 1970s and has adjusted to the labor market changes many times since then (Pakkala 2014). In our sample, participants aged 59 years and older were eligible for the unemployment pathway to retirement, providing them with an option to retire early. Although there are specific regulations any dismissal decisions need to follow, such as considering employee seniority, these negotiations have gained an ageist reputation within the public and are claimed to be used for 'cleansing the company' of its older employees. For instance, Pärnänen (2012) analyzed interviews with employees from ten work organizations in Finland and found mixed opinions about their intentions to leave. While some older employees were willing to take an early retirement through the unemployment pathway, others felt pressured to retire earlier than they wanted.

When a work exit occurs close to retirement age, the person in question may be hard-pressed or unable to find other employment until their old-age pension starts, and they may need to take the unemployment path to retirement. In our study, the official boundaries of who left Posti voluntarily and who was made to leave are somewhat blurred by the participants' self-identified descriptors for their various situations. Some participants said they resigned, some said they were dismissed, and others were officially dismissed but expressed a desire for this outcome.

\section{Participants}

Our selection criteria for the 20 interviews analyzed in this paper were that, during the longitudinal interview study, the participants reported having taken some route to retirement after leaving Posti and this had then resulted in either full-time or part-time retirement or an unemployment pathway to retirement. Our participants had left Posti as a result of a procedure known as cooperative negotiations (Finnish: yhteistoimintaneuvottelut). Our sample of participants included 11 women and nine men. At the time of the interviews, they were approximately 55-65 years of age. Their occupations within Posti were diverse, with seven having worked in white-collar positions and 13 in blue-collar. Many of our participants had low-level education backgrounds and had received task-specific training from Posti during their often decades-long careers there. For demographic data on our participants, see Table 2 .

\section{(C) $(1) \odot$}


Table 2 Participants' demographic data

\begin{tabular}{|c|c|c|c|c|c|}
\hline $\begin{array}{l}\text { Participant } \\
\text { No. } \\
\text { (F = female, } \\
\text { M= male) } \\
\text { + Pseudonym }\end{array}$ & $\begin{array}{l}\text { Age } \\
\text { group* }\end{array}$ & $\begin{array}{l}\text { Work type } \\
\text { (Blue/White } \\
\text { collar) }\end{array}$ & $\begin{array}{l}\text { Marital/ } \\
\text { Partner } \\
\text { status }\end{array}$ & Healthstatus & Financial status \\
\hline FI. Mari & under 59 & Blue & $\begin{array}{l}\text { Married, husband } \\
\text { to retire in I year }\end{array}$ & Health issues & $\begin{array}{l}\text { Secure due to } \\
\text { husband's income }\end{array}$ \\
\hline M2. Mika & $63+$ & Blue & $\begin{array}{l}\text { Married, wife still } \\
\text { working }\end{array}$ & Health concerns & Secure and stable \\
\hline M4. Pentti & $63+$ & Blue & $\begin{array}{l}\text { Divorced, living } \\
\text { alone }\end{array}$ & Maintains health & Secure and stable \\
\hline M5. Juho & $63+$ & Blue & $\begin{array}{l}\text { Married, wife still } \\
\text { working }\end{array}$ & Maintains health & $\begin{array}{l}\text { Secure; earns more } \\
\text { to support children }\end{array}$ \\
\hline M6. Ilmari & $59-62$ & White & $\begin{array}{l}\text { Married, wife still } \\
\text { working }\end{array}$ & $\begin{array}{l}\text { Good health } \\
\text { (developed ill- } \\
\text { ness later during } \\
\text { follow up) }\end{array}$ & $\begin{array}{l}\text { Secured and plans } \\
\text { on finding a nice } \\
\text { new job }\end{array}$ \\
\hline M7. Jyri & $59-62$ & White & $\begin{array}{l}\text { Married, wife's } \\
\text { working status } \\
\text { unknown }\end{array}$ & $\begin{array}{l}\text { Positive changes } \\
\text { in health after } \\
\text { retirement }\end{array}$ & $\begin{array}{l}\text { Stable and secure; } \\
\text { thinks about work- } \\
\text { ing a few extra } \\
\text { days a month }\end{array}$ \\
\hline F8. Anna & under 59 & Blue & $\begin{array}{l}\text { Married, husband } \\
\text { retired three } \\
\text { years earlier }\end{array}$ & Health issues & $\begin{array}{l}\text { Looks after finances } \\
\text { more carefully now; } \\
\text { farmer's pension se- } \\
\text { cures finances until } \\
\text { retirement age }\end{array}$ \\
\hline M9. Ismo & $59-62$ & White & $\begin{array}{l}\text { Married, wife still } \\
\text { working }\end{array}$ & Health issues & $\begin{array}{l}\text { Income drop since } \\
\text { being employed but } \\
\text { happy with his life }\end{array}$ \\
\hline MII.Petri & $59-62$ & White & $\begin{array}{l}\text { Married, wife's } \\
\text { working status } \\
\text { unknown (pos- } \\
\text { sibly retired) }\end{array}$ & $\begin{array}{l}\text { Maintains health } \\
\text { through PE }\end{array}$ & $\begin{array}{l}\text { Income set to rise } \\
\text { again after pension; } \\
\text { stable and secure }\end{array}$ \\
\hline MI3. Pertti & under 59 & White & $\begin{array}{l}\text { Divorced, living } \\
\text { with partner }\end{array}$ & Health issues & Stable and secure \\
\hline FI6. Liisa & $59-62$ & Blue & $\begin{array}{l}\text { Divorced, living } \\
\text { alone }\end{array}$ & $\begin{array}{l}\text { Maintains health } \\
\text { through PE }\end{array}$ & $\begin{array}{l}\text { Stable and waits } \\
\text { for retirement }\end{array}$ \\
\hline F20. Hannele & $59-62$ & Blue & $\begin{array}{l}\text { Divorced, pos- } \\
\text { sibly living alone }\end{array}$ & $\begin{array}{l}\text { Minor back } \\
\text { issues, otherwise } \\
\text { good }\end{array}$ & $\begin{array}{l}\text { Has taken } \\
\text { unemployment } \\
\text { pathway }\end{array}$ \\
\hline F21. Kaisa & $59-62$ & Blue & $\begin{array}{l}\text { Divorced, } \\
\text { partner, not living } \\
\text { together }\end{array}$ & Health issues & $\begin{array}{l}\text { Applied for part- } \\
\text { time disability } \\
\text { pension; has taken } \\
\text { unemployment } \\
\text { pathway }\end{array}$ \\
\hline
\end{tabular}




\begin{tabular}{|c|c|c|c|c|c|}
\hline $\begin{array}{l}\text { Participant } \\
\text { No. } \\
\text { (F = female, } \\
\text { M = male) } \\
\text { + Pseudonym }\end{array}$ & $\begin{array}{l}\text { Age } \\
\text { group* }\end{array}$ & $\begin{array}{l}\text { Work type } \\
\text { (Blue/White } \\
\text { collar) }\end{array}$ & $\begin{array}{l}\text { Marital/ } \\
\text { Partner } \\
\text { status }\end{array}$ & Healthstatus & Financial status \\
\hline F22. Maikki & Under 59 & White & $\begin{array}{l}\text { Married, both } \\
\text { 'retired' at the } \\
\text { same time }\end{array}$ & Good health & $\begin{array}{l}\text { Financial situation 'is } \\
\text { not a catastrophe' }\end{array}$ \\
\hline F24. Siru & $59-62$ & White & $\begin{array}{l}\text { Married, husband } \\
\text { retired earlier }\end{array}$ & $\begin{array}{l}\text { Good health, } \\
\text { some issues in } \\
\text { the past }\end{array}$ & $\begin{array}{l}\text { No financial issues; } \\
\text { wants to find a job }\end{array}$ \\
\hline F25. Helvi & $59-62$ & Blue & $\begin{array}{l}\text { Married, husband } \\
\text { retired earlier } \\
\text { same year }\end{array}$ & $\begin{array}{l}\text { Good health, } \\
\text { goes to the gym } \\
3 \text { times a week }\end{array}$ & $\begin{array}{l}\text { Stable and secure } \\
\text { financial situation }\end{array}$ \\
\hline F28. Maisa & $59-62$ & Blue & $\begin{array}{l}\text { Married, husband } \\
\text { still working }\end{array}$ & Health issues & $\begin{array}{l}\text { No need to find job } \\
\text { because no financial } \\
\text { musts }\end{array}$ \\
\hline M30. Veli & $63+$ & Blue & $\begin{array}{l}\text { Married, wife still } \\
\text { working }\end{array}$ & $\begin{array}{l}\text { Health concerns } \\
\text { and issues }\end{array}$ & $\begin{array}{l}\text { No worry over } \\
\text { finances }\end{array}$ \\
\hline F34. Leena & $59-62$ & Blue & $\begin{array}{l}\text { Married, husband } \\
\text { still working }\end{array}$ & Health issue & Stable and secure \\
\hline F36. Ulla & $59-62$ & Blue & $\begin{array}{l}\text { Married, husband } \\
\text { a gradually retir- } \\
\text { ing entrepreneur }\end{array}$ & $\begin{array}{l}\text { Health issues } \\
\text { from involun- } \\
\text { tary dismissal, } \\
\text { self-estimated } \\
\text { stress reaction }\end{array}$ & $\begin{array}{l}\text { Advance early } \\
\text { retirement pension } \\
+ \text { earnings-based } \\
\text { financial support, } \\
\text { secured and stable }\end{array}$ \\
\hline
\end{tabular}

*Age categorized according to unemployment pathway and pension eligibility during the first interview as follows: Under 59: Below unemployment pathway eligibility

59-62: Eligible for unemployment pathway

63+: Eligible for old-age pension

\section{Interviews}

Our data consist of 20 out of 40 thematic, first-round, face-to-face, individual interviews conducted in 2015-2017 during the longitudinal Toward a two-speed Finland? (2TS 2016) research project. The semi-structured interviews were conducted nationwide by two experienced postdoctoral researchers; the interview locations were chosen by the participants and interviews most often took place in participants' homes. The interviews were recorded and then transcribed by an external company. Our selected interviews lasted 34-130 minutes (average duration: 65.85 minutes). Participants were asked about their career, the process by which they left work, and their life and future goals after work, as well as how they feel about the steps of the retirement process. They were also asked to assess their overall life satisfaction and work life satisfaction at different ages, and to relay their thoughts concerning the Finnish government's goal of extending work careers. 


\section{Analytical approach}

We applied a thematic content analysis, as outlined by Uwe Flick (2014). The method was chosen based on its reported flexibility and easy adaptation to various theoretical frameworks and methods (Braun \& Clarke 2006). Our theory-driven thematic analysis was guided by Jyrki Jyrkämä's (2008) model of agency. As our dataset was pre-transcribed, we familiarized ourselves with the data during the coding and translation of coded and directly quoted passages into an Excel spreadsheet. The six modalities acted as categories. During coding, we found that drawing strict boundaries between the categories was difficult. The subsections in our Results section represent what we saw as the most dominant modalities in the situations described.

In this study, agency is identified through the six modalities outlined by Jyrkämä (2008): Be Able, Must, Can, Feel, Want, Know-How. Following Jyrkämä's 2008 article, we will also present our observations on the combinations of these modalities that dynamically form the individual's agency. As we illustrated with Juha's case, within these modalities, there can be many considerations both for and against a work exit.

\section{Results}

The modalities Can and Must include structural factors, which may either limit or enable individual actors. In what follows, we will explore the connections between these two modalities and the four other modalities to identify dynamics that appear between structures and agency in situations where an older employee leaves a long-term employer. This exploration reveals the complexity of late-career work-exit situations and the agency present therein: in many instances, one or two modalities appear entwined and in opposition to Can and/or Must. Table 3 summarizes the intersections we found in the data between the structural modalities Can and Must with the remaining four modalities.

Table 3 How Can and Must manifested in relation to the other four modalities in the data

\begin{tabular}{|c|c|c|}
\hline & Can & Must \\
\hline Know-How & Re-education opportunities & External imperatives for continued learning \\
\hline Be Able & $\begin{array}{l}\text { Work ability and opportunities for } \\
\text { rehabilitation or early retirement }\end{array}$ & $\begin{array}{l}\text { New work demand hindering wellbeing at } \\
\text { work; inability (actual or assumed) to meet } \\
\text { these demands as retirement rationale }\end{array}$ \\
\hline Want & $\begin{array}{l}\text { Wishing to retire together with financial } \\
\text { opportunity; refusals of job opportunities }\end{array}$ & $\begin{array}{l}\text { Wanting to work until or past official } \\
\text { retirement age but not being allowed to }\end{array}$ \\
\hline Feel & $\begin{array}{l}\text { Context for dismissals and motivation for } \\
\text { resignations; negative perceptions of changes } \\
\text { and demands }\end{array}$ & $\begin{array}{l}\text { Moral negotiations concerning employment } \\
\text { and income situations; concern for younger } \\
\text { people's employment }\end{array}$ \\
\hline
\end{tabular}

As some of our participants reported feelings of unease and shame for their layoff and/ or unemployment, it is interesting to note that being dismissed would actually present itself as a more favorable option for other participants. Age norms and personal values of work as an intrinsic good may come into play here, and what a person wants may 
eventually tip the scales in favor of either option when facing a decision between being made to leave and choosing to leave. We will now go over our more detailed analysis of the modalities Know-How, Be Able, Want, and Feel and how they relate to each other and the modalities Can and Must in our data.

\section{Know-How}

Know-How includes the individual's acquired skills and knowledge, for example, tacit knowledge and education. In our data, Know-How and Can intersect in accounts of added schooling and re-education opportunities in cases where chances to add to one's expertise were either limited by others (e.g., employer or unemployment office) or assessed as redundant by the participant.

For Siru (F24), Know-How appeared in combination with the modalities Want and Feel. Siru spoke of her education and expertise as achievements (Feel) and as something she wanted to continue making use of (Want). She had expertise on project work and was involuntarily dismissed close to the end of one project which, she reports, negatively impacted her work motivation and colored her experience of her remaining time at Posti. She remembers:

And this isn't the only project that I was directing there, the previous project was also big and challenging. So I was terribly irritated that the company no longer needed its own people of this sort, meaning that if there is another project, then you recruit them, take them in for the duration of it from outside. And this is a very typical way of doing things, and this is what I'm actually trying to do myself now. Like, if I could get into another company, sort of go into companies just to do some project.

The structural changes and skill redundancy articulated here follow Jyrki Jyrkämä's (2008) definition of Must as external limitations or hindrances, which in turn oppose the entwined modalities of Know-How and Feel. While Siru was looking for other work and going to job interviews, she also had plans to start her own consulting business on old-age pension. This was so that she could make use of (Want) her accumulated education and expertise (Know-How). She also mentioned plans for what might be termed as outsourced or shared Know-How in relation to her own business: she was hopeful that she would find a business partner with more experience in sales and marketing, so she would not have to know everything.

Mari (F1) articulated the limits of her professional Know-How as her having mainly worked in postal deliveries and other types of blue-collar, heavy manual labor with a basic-level compulsory education background. Mari states that her physical ailments dictated her early exit from this type of work but she felt that she might have been able to work with customers or in a more white-collar type of job. Here, Must and KnowHow are joined by Be Able and Feel. Mari added that, in order to do this, she would have had to re-educate herself, and she estimated that this would have been a very laborintensive endeavor and a waste of societal resources because of her age (Feel vs Can), level of education (Know-How) and work ability (Be Able).

So what sort of job can a person my age train into? These days, they train you up to almost be a practical nurse and caregiver for grannies, and I'm in no condition to be lifting 
grannies, you know, since I can't even carry a bag of groceries. So I'd have to get educated up to at least a university level, and on top of that I'm already so old [laughs] that it just makes no sense, like I have in all honesty given up on that since it makes no sense ...

Here, the imperative for reeducation (Must) and the opportunity for reeducation (Can) are in opposition to her situational assessment (Feel) and consequent decision (Can).

In sum, Know-How manifested as wanting to make use of, having to keep up, and having untapped potential, sometimes in combination with assessments of one's personal situation not allowing them to pursue education opportunities. Here, Must appears as external hindrances in the form of dismissals and work demands, while Can appears as re-education opportunities and decisions concerning them.

\section{Be Able}

Be(ing) Able includes reports of an individual's physical and mental capabilities. In relation to Can, these appeared in participant accounts concerning work ability and opportunities for either rehabilitation or retirement. Must appeared in connection to Be(ing) Able in accounts of new work demands that were perceived to hinder physical or mental wellbeing at work in some way or were used as rationale for recommending retirement. Impaired work ability also appears to have influenced retirement decisions and these varied between having the added financial opportunity to retire (Can) and having no choice but to retire $(M u s t)$.

Maisa (F28), who resigned voluntarily, says that she feels better now that she can vary her physical activities throughout the day: at work, high productivity goals drove people to stay in their seats, indicating the presence of a social Must that conflicted with the theoretical opportunity to move around (Can).

... and I have found that I feel a whole lot better now because throughout the day, I can do - I can sit, and I can walk around and do a bit of exercise every now and then. At work, although there should be, and we do sort of - we had the license to take breaks and walk around every now and then, but basically it was this thing where we have these staggering goals, so you did end up just staying seated. And then, of course, the manager would come along to see what this person is [doing] and comes up and says, 'What are you doing? Aren't you working?' if you're doing something else over there.

In this account, Can is also representative of how the respondent perceives her current situation as positively impacting her physical wellbeing, whereas the contrasting assessment of her recent past at work illustrates how the external Must of productivity is seen as having had a negative impact on her wellbeing. There were other similar reports of excessive monitoring by managers as a perceived negative influence on wellbeing at work. Maisa also reports having had problems with her wrists and back, with surgeries and sick-leaves in the past, and says that this was also a factor in her decision to retire sooner. Here, Be(ing) Able intersects with Can by influencing Maisa's decision to leave work.

Mika (M2) resigned after being persuaded by his managers during cooperative negotiations; he was told that new job demands (Must) would not suit someone his age, 
and that as he had already reached retirement age, resignation with a severance package would be the best option for him (Can). Here, the presence of Can as a retirement opportunity due to age is equated with age-related impaired work ability (Being Able) by people essentially responsible for enforcing the company's imperative for reduced employee numbers during cooperative negotiations and increased efficiency in operations (Musts).

Mika ultimately perceived this persuasion as a show of consideration for him (Feel). However, he also states that he was in good shape and had taken very few sick-leave days during his time at Posti: 'They just thought about my best interest, like "you might not be able to work these workdays". [But] I was back there the next summer. I've worked there [on and off] since then'. He had signed up to come in and help where needed and did work for a couple of weeks in deliveries, stating that he 'had the physique' and the expertise, although he says that it was quite grueling work. Mika's assessment of his Be(ing) Able, therefore did not match that of his managers.

In sum, $B e$ (ing) Able appeared in participant accounts concerning work ability and rehabilitation or retirement opportunities. Must appeared here as new work demands that somehow hindered wellbeing at work, as retirement recommendation rationale, or as an internal Must in having no choice but to retire. Can appeared as work exit decisions influenced by either impaired work ability or preserving future health. Can also manifested as financial retirement opportunities.

\section{Want}

Want includes the individual's desires and motivations. Accounts in our data which manifested Want in combination with Can included reports of wanting to retire and having the opportunity to do so financially, as well as refusals of opportunities (e.g., a job offer). Must appeared in accounts where participants had wanted to work until or past retirement age but were not allowed to by their employer, or efficiency goals did not allow the participant to do as good a job she would have liked. Want also manifested as a desire for a different outcome in the negotiations, as people took action to fight the closure of their workplaces and wished for an opportunity to 'retire honorably'.

Leena (F34) resigned voluntarily, since her other option would have been not to leave (Can) but then, she says, she would have been dismissed, which would have obliged her to work for longer than she was willing to (Must vs Want).

Q: So you applied for the [severance package option to voluntarily resign].

A: Yeah I applied almost right away. It clicked for me immediately that this was probably it since I think there was the option of not resigning, and you'd have been made redundant anyway, so there would have been an obligation to work. I would have had to drag on until fall. And that was not something I was interested in anymore.

This account demonstrates an intersection of Can and Must with Want: Leena had a choice in her work exit but her options were not equal in terms of the desired outcome. She also reported that, before the cooperative negotiations, she had not considered leaving altogether but had rather thought about taking a part-time retirement to lighten her workload, indicating a hypothetical decision ( $\mathrm{Can}$ ) to keep working in some capacity. 
Jyri (M7) decided against resignation and was dismissed, that is, the decision not to leave voluntarily (Can) was followed by an external imperative to leave (Must). Jyri says he declined the position he was offered because his title would have changed $(\mathrm{A} / \mathrm{N}$ : possibly denoting added duties for the same salary). As noted previously, the refusal of what appeared to be an inferior job opportunity was a common theme among our white-collar male participants.

Jyri and his colleague had observed cooperative negotiations resulting in layoffs of younger employees; older employees kept their jobs based on seniority but actually hoped for a way out: 'And there were some six, seven people aged over 60 there. And a lot of them would have wanted to leave'. Jyri states that 'luckily' two other people, one of them younger but still close to retirement age, were able to get the jobs Jyri and his colleague vacated: '... when we managed to get ourselves out of there, they got our jobs'. In these statements, Want and Can manifest as a motivation and a decision, respectively. In this case, the motivation relates to external Musts, that is, company policies concerning seniority during co-operative negotiations.

Siru (F24) says that she would happily give up her unemployment support in favor of running her own business but that the current system does not provide any leeway for starting and making a business profitable: 'This is a completely stupid system ... you should be able to start a business and once it starts making, let's say a certain amount of money, then the subsidies would end'. Her age still disqualified her from applying for old-age pension, which would have allowed her to realize her plans. The modality of Must manifests here as hindrances to opportunities (Can).

In sum, Want appeared in reported desires to retire, either early or later, after the official retirement age. For those motivated to retire early, cooperative negotiations with their promise of a severance package for voluntary resignations appeared as an opportunity (Can). Must was mainly present in accounts where desires for extended work careers were impeded by an external imperative posed by the employer to leave work. One participant's plans for entrepreneurship were hampered by financial sanctions to people on unemployment support (Must vs Can). It is also interesting to note here that the line between imperative and choice to leave work did not neatly follow the lines between resignation and dismissal.

\section{Feel}

Feel includes the individual's emotional responses, situational assessments, and value judgments. Assessments of the current situation appeared in most of our 20 interviews and acted as motivation for voluntary resignations, and as context for involuntary dismissals. In some interviews, age appeared in assessments that this was an opportune moment to leave work: retirement age was close and the severance package awarded to voluntary resignations became available to the participants. Added to the perceived financial opportunity ( $\mathrm{Can}$ ), negative perceptions of organizational changes (Feel) and efficiency demands (Must) were also present.

Kaisa (F21) was involuntarily dismissed and felt ashamed for her layoff and subsequent unemployment status. She had even applied for a disability pension to 'feel like [she's] a person too since [she'd be] on a pension'. Here, hierarchies are articulated based on value judgments regarding volition and perceived social rights: disability pension is 
raised above unemployment, and dismissal is seen as categorically shameful. Veli (M30), who voluntarily resigned, says that work has been very important to him and that he does not know 'what would have happened if they'd kicked [him] out'. This account also demonstrates the perceived importance of having a choice (Can).

Toward the end of her career, Kaisa states that efficiency goals (Must) got in the way of her job satisfaction and that not being allowed to do her job according to her standards influenced her wishes to leave Posti. Here, Feel and Want are entwined and in opposition to Must. Kaisa also articulates a fear of and rebellion against returning to work: she says she is afraid that she might get re-recruited, but even under a threat of financial sanctions from unemployment officials, she has decided that she will not go back. Kaisa states that her friends have told her not to worry: 'They won't [ask you], you're so old', but following the news still makes her skeptical:

... but based on the story yesterday, our impression was that [Posti] are constantly having to seek out [employees]. They aren't able to get them. And I've been to see the application and [it says] you need to have proficiency in Swedish and English. And now I've heard that there are also people with no language proficiency who have been [hired] there, meaning they can't get a qualified applicant. Or employee. That's why I'm scared.

Here, two Musts, (1) the employer's obligation to first offer work to layoffs within six months of their contracts ending, and (2) her obligation as an unemployed jobseeker to accept job offers, work against Kaisa's personal desire (Want) to not return to Posti. Her fears were further exacerbated by news reports of Posti having difficulties recruiting new staff, contributing to a situational assessment (Feel) that she might very well be recruited based on her previous work experience (Know-How).

For some of our participants, retirement age was close and several previous, consecutive cooperative negotiations had enforced the idea that one might be dismissed and the participant decided to resign.

Helvi (F25) states that she voluntarily resigned when the severance pay opportunity presented itself. She says she was tired of the constant cooperative negotiations at Posti (the previous ones having been held the preceding fall) and that she no longer truly enjoyed her job (Feel). Helvi also says that she has since wondered why she was so certain that she would be dismissed and whether she had any reason to think she would be $($ Feel). She has thought about whether it might have been to do with her age (Feel):

And I have thought about it, after the fact, about why I was so sure that I'd be dismissed, even when I [didn't] know if I had a real reason to believe that I would have been. I thought about my age but there were better people than me working there. In this last job, there was also this thing where the managers were terribly young, and that was pretty strange to me as well, so ...

It seems possible that her situational assessment (Feel) regarding her age and future in Posti and her emotional response to her work (Feel) added to the financial incentive $(\mathrm{Can})$, which worked in tandem to support her decision to resign (Can). Helvi also says that, having always worked, being on unemployment support feels wrong to her, 'undeserved'. She goes on to state that she 'of course' shouldn't think this way, since she has 'worked and paid, I guess, my fair share of taxes, so'. Feel manifests in this negotiation as value judgments. 
In sum, Feel appeared in most participants' accounts of their work exit, for example, as situational assessments of impending dismissals due to age or lacking expertise, and as emotional responses and negotiations concerning employment and income. Can manifested here as financial structures (e.g., pension or unemployment support), which elicited varying emotional responses, ranging from perceiving unemployment support as 'undeserved' or 'shameful', to more generally positive responses to old-age pension, which was perceived as generally deserved after a long work career. One participant had applied for a disability pension in order to change her status from unemployed to pensioner, estimating that this would make her feel like '[she's] a person too'. Must manifested as an external imperative to leave in accounts where participants felt that they were 'cast aside' via dismissal after 'a long service'.

\section{Summary}

To summarize our analyses, the structure-bearing modalities Can and Must appeared differentially in relation to the modalities Feel, Want, Know-How, and Be Able in former postal workers' interview accounts concerning late-career work exit situations. Can entails opportunities and choices, as we identified it in reports relating to rehabilitative experiences concerning work ability and as opportunities to leave work early where work ability was limited (Be Able), to wishes concerning early retirement bolstered by the financial opportunity afforded by a severance package and refusals of 'bad' job offers (Want), to opportunities for re-education and the choices concerning them (Know-How), and to situational assessments and perceptions which provide context and, in some cases, what appears to be motivation for work exits (Feel).

Must, on the other hand, contains imperatives and limitations, which we identified in accounts concerning negative effects on wellbeing from new work demands and, in one case, manager assumptions concerning work ability after a certain age (Be Able), unrequited wishes for a late or early retirement (Want), upkeep of professional knowledge as an external imperative, and in some cases, a burden (Know-How), and in moral judgments and negotiations concerning unemployment support and concern for other people's unemployment (Feel). Can and Must also sometimes appeared in opposition to each other, in various combinations with the other modalities and without them.

\section{Discussion}

Despite choosing participants who had more or less chosen to retire, leaving a longterm workplace near official retirement age appears to be a more blurred (Gilleard \& Higgs 2000) and multifaceted phenomenon than a straight-forward progression into full-time retirement. The heterogeneity of retirement experiences is further supported by our agency analysis, which shows how people experiencing the same event consider different aspects depending on their situation.

To paraphrase Pirhonen and Pietilä (2018), agency is not only confined to taking the initiative but can also involve delegating actions to someone else while the subject remains in charge of that decision. In our data, this can be seen in situations where participants allowed themselves to be dismissed instead of voluntarily resigning. This 
became apparent in instances where participants reported, for example, being offered new job opportunities but declining them, deciding to let themselves be dismissed instead of voluntarily resigning, or voluntarily resigning without the external pressure of needing staff reductions at their workplace.

Can appeared as opportunities and incentives to leave work, keep working, or add to one's professional skill set, while Must manifested in imperatives to add to one's professional skill set, to work more efficiently, or to leave work. However, the structurebearing modalities Can and Must, while certainly influential to retirement outcomes and experiences in the form of organizational influence, were only instrumental to a degree in determining individual agency as a whole.

By this, we mean that our participants were active in not only making decisions about their retirement, within structural limitations, but also in constructing their individual experiences concerning the process by which their work exit came about. They retroactively negotiate the reasons for their work exits, their reports manifesting various combinations of the six modalities of agency. We must, of course, not dismiss the structural factors present in retirement outcomes, as societal institutions and employing organizations play a large role in them (see, e.g., Pärnänen 2012; Vickerstaff 2006).

Financial incentives include both the severance packages from Posti and financial support from the Finnish state (e.g., pensions, unemployment support). Paired with a fatigue from constant change, they were present in several late-career work exit accounts in our data. They were also reflected in doubts about future pensions, and uncertainty about 'how things will turn out'. These concerns appeared in some participants' accounts of choosing to leave Posti employment before official retirement age, if they were close to retirement age at the time of the cooperative negotiations. Some participants reported that the recurring cooperative negotiations had added to a general atmosphere of uncertainty and caused tension at work. The employing organization's financial incentive was also mentioned by many participants as an initial inspiration to even start considering retirement. Furthermore, our data revealed that, despite political efforts to prolong working careers, many employees opt to follow normative ideas about working age, stating, for example, that they had 'done their share' as employees and/or taxpayers and that now was their time to relax.

In line with our research results, Hermansen and Midtsundstad (2018) illustrate that financial incentives can only explain a fraction of early retirement behavior in Norway. Berglund et al. (2017) found that a decline in work ability and financial incentives in the form of a recent pension reform were likewise limited as an explanation, and give credit to norms and values.

Although our male participants appear to have had more choice regarding work exit, all of our participants demonstrated agency within the confines of their situation, and this manifested in varying modality combinations. Health concerns were cited more often by female than by male participants as a work exit reason. For women under age 60 , work exit accounts included reports of poor work ability in the present, while the men were all aged over 60 years, and many of our white-collar male participants chose to decline late-career job offers to preserve their remaining health. These things could be indicative of gendered ageism, differentially affecting men's and women's job opportunities (see also McGann et al. 2016).

Age-related norms were present in some of our participants' accounts of their decision to leave Posti. One male participant reported being persuaded to resign based 
on a perceived poor fit between future work demands and the physical abilities of someone his age. One female participant perceived re-education into a type of work better suited to her limited work ability as a wasted effort due to her age. Some of our female participants reported age as one of the reasons they assumed they might be let go during cooperative negotiations, and that they decided on a voluntary resignation to avoid this.

Our participants articulated ideas about cooperative negotiations as an opportunity or the 'right' time to retire. These ideas appeared to be based on varying combinations of the following: financial incentives, common knowledge concerning past cooperative negotiations and chronological age as a potential layoff criterion that served the company's economic goals, concern for matters such as other (younger) people's continued employment, concern for one's health, now or in the future, and seeing retirement after a long career as a social right.

Tulle (2004) argues that the dominant, and largely unquestioned, discourses around aging and older people revolve around decline, either postponing it or being 'caught up by it', which impacts both individuals and institutions and restricts older people's agency (Tulle 2004, p. ix). Tulle emphasizes '... the liberation of older people from restricted narratives and consequently restricted identities' and the importance of critiquing structures (Tulle 2004, p. ix). This could, in turn, assist in improving not only labor market age policies (see Pärnänen 2012) but also the overall quality of life of aging individuals.

Consistently with Krekula (2019), our data included individual mentions of wanting and being able to work past 63, 65, or even 68 years, but under the right conditions, for example, being able to adjust the work to the individual's abilities in terms of work content (such as customer service or desk jobs instead of mail delivery, or adjusting delivery routes based on the employee's ability) or work time and having more choices concerning one's duties.

The findings of Higgs et al. (2003) resonate well with ours, as our participants also often reported either being motivated by financial rewards offered to those who resigned, feeling the pull of added free time, or being dissatisfied with some aspect of their current work or job offer. Our data illustrate that older employees are not a homogeneous cohort and should not be treated as one. Changes in the organization of work and perceptions of aging and older employees may be in order for employers, and for the employees themselves, in order for working at older ages to be seen as a viable option (see Pärnänen 2012). Our participants' heterogeneity is also illustrative of Vickerstaff's (2006) observation about the present, individualized nature of retirement transitions.

Employers may also need new ways of recognizing and retaining those older employees who are motivated and able to continue working with the right adjustments and who can offer a wealth of job-related tacit knowledge, for example, as mentors for younger employees. Alternatively, or perhaps additionally, they could look into ways of providing support for more sustainable work-lives, overall. Mulders and Henkens (2019) studied Dutch employers' HR policies and found that a large number of them had begun 'to implement HR practices to adjust to the reality of longer working lives' and that these included measures that 'aimed at providing information, enhancing the workability and health of employees, and improving their person-job fit' for all employees rather than specifically targeting older employees (Mulders \& 
Henkens 2019). We posit that Jyrki Jyrkämä’s (2008) agency model has potential as an analytical tool for mapping out ways to sustainably extend work careers, either way.

Our data also included reports indicating that retirement decisions are not made in a vacuum, and that individuals are influenced by not only the employing organization but also by their friends, coworkers and family. Spouses may make joint considerations concerning finances; coworkers and friends may comment on what they see as a beneficial course of action or may otherwise inform the decision-making process. Examples of this were accounts by our male participants in which deaths of recently retired friends in similar work positions were articulated as further considerations in their decision to retire close to official retirement age.

\section{Strengths and Limitations}

A structuralist, theory-driven approach that seeks to discover themes based on predetermined criteria (the six modalities and their operative definitions) in qualitative interview data may raise concerns that individual experiences were, in the process, reduced to fit a mold that is not an accurate representation of the messy reality of human experience. However, we do not seek to make general assumptions concerning all retirement experiences. Rather, we have sought to test a tool that may be used in future studies on aging individuals' agency in the context of work. Care must be taken not to make unfounded inferences regarding causality in data such as ours. We have sought to avoid this by closely paraphrasing or directly quoting our participants' accounts of their work exit situations.

Jyrki Jyrkämä's (2008) modality-based agency model was not a consideration in the 2 TS project's original research design. This could increase the reliability of our study, as the participants were not conditioned to produce accounts specifically about agency. Furthermore, thematic analysis in combination with flexible categories during coding and modality combinations employed in reporting our results provide further assurance that our descriptions and their analyses accurately represent the manifold and complex retirement experiences present in our data.

Though still somewhat unknown to international audiences, the undeniable strength of Jyrkämä's model is that it understands agency as the situational interplay of structural, internal, and demographic factors. It helps us see work ability and various individual and structural job-related push and pull factors as parts of a larger whole: the individual older employee's agency. Work ability (Being Able), financial incentives (Can), and personal and societal norms (Must) can be studied alongside each other and other dimensions involved in retirement decisions, such as family relations (Feel and Must), assessments and emotional responses regarding one's job, manager and/or coworkers $($ Feel), desires regarding free time (Want), and one's education level and task-specific skill set (Know-How).

While showing undeniable promise and substantial contributions to existing discussions, Jyrkämä's model also has its limits in analyzing retirement situations, particularly in terms of generalizability. Nevertheless, it does offer a way to focus on the heterogeneous life situations and decision-making processes of older employees. In this way, it contributes to undoing harmful stereotypes related to aging at work by broadening the fairly narrow and limited publicly held image of the older employee.

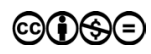




\section{Conclusion}

Our study focuses on agency in work exit interview accounts of people who were near retirement age and had recently experienced co-operative negotiations to determine continued employment either personally or vicariously, that is, as an event that affected others at their workplace or employing organization. They had spent decades in the service of a state-owned and once famously reliable employer that had, in the recent decade, implemented several wide-scale negotiations that led to staff reductions. Via thematic analysis and utilizing Jyrki Jyrkämä's (2008) agency model as our theoretical framework, we explored how manifestations of the modalities Can and Must, which carry structural aspects with them, interacted with the modalities Be(ing) Able, KnowHow, Want, and Feel in individual interview accounts. The purpose of this was to study the agency of older employees and to test the usability of Jyrkämä's model in a work-life related study context. We confirmed our participants as a heterogeneous group, and that agency was manifested in many different modality combinations among older employees depending on their personal situations. Two common themes among our participants were changes at work and financial incentives offered to early retirees by the employing organization. Accounts reporting changes at work entailed situational assessments that it was 'time to leave' and there was no desire to keep 'dragging on' (Feel), while financial incentives were seen as opportunities (Can).

We conclude that Jyrkämä's modality-based approach to agency provides a multifactorial framework for studying aging employees as individuals with agency. We must not overstate the role of individual agents since, as previous research shows, and as our data also demonstrate, retirement outcomes are still greatly influenced by the employing organization and societal structures, such as the pension system. However, structural factors also have a limited impact on retirement outcomes when it comes to extending work lives.

In this article, we have demonstrated that if we wish to extend retirement age, older employees' sense of agency should be considered by taking people's physical and mental capabilities, desires, work-related values, expertise, and individual life situations into account in work planning and work demands. Furthermore, we have shown that Jyrkämä's model adds to and expands the existing discussions. We suggest that the dynamics between modalities need more extensive exploration, and we wish to explore them further in our future papers.

\section{Acknowledgements}

This project has received funding from the Kone Foundation and the European Union's Horizon 2020 research and innovation program under the Marie Skłodowska-Curie grant, agreement No 764632 .

\section{References}

2TS (2016). Towards a Two-Speed Finland? Longer Working Life, Retirement Pathways and Inequality. http://www.uta.fi/yky/2ts/en.html, Accessed 29 August 2019. 
Berglund, T., Seldén, D., Halleröd, B. (2017). Factors affecting prolonged working life for the older workforce: the Swedish case, Nordic Journal of Working Life Studies 7(1): 19-36. doi: http://dx.doi.org/10.18291/njwls.v7i1.81396.

Braun, V. \& Clarke, V. (2006). Using thematic analysis in psychology, Qualitative Research in Psychology 3(2): 77-101. doi: http://dx.doi.org/10.1191/1478088706qp063oa.

Bytheway, B. (2005). Ageism and age categorization, Journal of Social Issues 61: 2, 361-374. doi: http://dx.doi.org/10.1111/j.1540-4560.2005.00410.x.

Eurofound (2019). Ageing workforce. https://www.eurofound.europa.eu/topic/ageing-workforce. Accessed 1 March 2020.

Finnish Centre for Pensions (2019a). Old-age pension: Birth year determines retirement age. https://www.tyoelake.fi/en/different-pensions/old-age-pension-birth-year-determinesretirement-agel, Accessed 12 May 2020.

Finnish Centre for Pensions (2019b). Security if you are elderly and unemployed. https://www.tyoelake.fi/en/different-pensions/unemployment-security-for-the-elderly/, Accessed 26 August 2019.

Flick, U. (2014). An Introduction to Qualitative Research. 5th edition, Los Angeles/London/ New Delhi/Singapore/Washington DC: Sage.

Giddens, A. (1984). The Constitution of Society: Outline of the Theory of Structuration, University of California Press, Berkeley and Los Angeles.

Gilleard, C. \& Higgs, P. (2000). Cultures of Ageing: Self, Citizen, and the Body, London: Pearson Education.

Hermansen, Å. \& Midtsundstad, T. (2018). The effect of retaining bonuses on delaying early retirement - financial incentives revisited, Nordic Journal of Working Life Studies 8(1): 43-64. doi: https://doi.org/10.18291/njwls.v8i1.104848.

Higgs, P., Mein, G., Ferrie, J., Hyde, M. \& Nazroo, J. (2003). Pathways to early retirement: Structure and agency in decision-making among British civil servants, Ageing \& Society 23: 761-778. doi: http://dx.doi.org/10.1017/S0144686X03001326.

Jolkkonen, A., Koistinen, P., Kurvinen, A. (2012). Reemployment of displaced workers - the case of a plant closing on a remote region in Finland, Nordic Journal of Working Life Studies, 2(1): 81-100. doi: http://dx.doi.org/10.19154/njwls.v2i1.2353.

Jyrkämä, J. (2008). Toimijuus, ikääntyminen ja arkielämä - hahmottelua teoreettismetodologiseksi viitekehykseksi. [Agency, ageing and everyday life - delineating a theoreticalmethodological framework. Translation by Author 1.] Gerontologia 4/2008: 190-203.

Kosonen, H. \& Keskinen, K. (2019). A modality-based agency analysis of voluntary vs. forced work exit near retirement age. Graduate thesis, Tampere University. http://www. urn.fi/URN:NBN:fi:tuni-201909133299, Accessed 3 September 2020.

Krekula, C. (2019). Time, precarisation and age normality: on internal job mobility among men in manual work, Ageing \& Society 39: 2290-2307. doi: http://dx.doi.org/10.1017/ S0144686X1800137X.

Krekula, C. \& Vickerstaff, S. (2019). Theoretical and conceptual issues in the extending working lives agenda. In Eds. Wendy Loretto, Sarah Vickerstaff, Áine Ní Léime, Debra Street and Clary Krekula. Gender, Ageing and Extended Working Life: Cross-National Perspectives. pp. 27-52. Policy Press, University of Bristol.

McGann, M. \& Bowman, D. \& Kimberley, H. \& Biggs, S. (2016). ‘Too Old to Work, Too Young to Retire': A Summary of the ARC Linkage Project: Understanding and Addressing Workforce Vulnerabilities in Midlife and Beyond 2012-2015. doi: http://dx.doi.org/10.13140/ RG.2.1.4711.0806.

Mulders, J. A. and Henkens, K. (2019). Employers' adjustment to longer working lives, Innovation in Aging 3(1): 1-10. doi: http://dx.doi.org/10.1093/geroni/igy040.

Organisation for Economic Co-operation and Development (2006). Ageing and employment policies: Live longer, work longer, Paris: OECD. http://www.oecd.org/employment/livelongerworklonger.htm, Accessed 1 March 2020. 
Pakkala, H. (2014). Työttömyysputki - Puolesta ja vastaan diskursiivisen hallinnan näkökulmasta [The unemployment pathway - Pros and cons from the viewpoint of discursive control]. Pro Gradu thesis, University of Jyväskylä. http://urn.fi/URN:NBN:fi:jyu-201409082749, Accessed 30 August 2019.

Perron, P., Collins, F. H., \& Collins, F. (1989). Paris School Semiotics: Volume I: Theory. Amsterdam: John Benjamins Publishing Company.

Pirhonen, J., \& Pietilä, I. (2018). Active and non-active agents: residents' agency in assisted living, Ageing and Society 38(1): 19-36. doi: http://dx.doi.org/10.1017/S0144686X1600074X.

Pärnänen, A. (2012). Does age matter in HR decision making? Four types of age policies in Finnish work organizations, Nordic Journal of Working Life Studies 2 (3): 67-88. doi: http://dx.doi.org/10.19154/njwls.v2i3.2364.

Solem, P. E., Syse, A., Furunes, T., Mykletun, R. J., de lange, A. H., Schaufeli, W. B., \& Ilmarinen, J. (2016). To leave or not to leave: Retirement intentions and retirement behaviour, Ageing \& Society 36(2): 259-281. doi: http://dx.doi.org/10.1017/S0144686X14001135.

Tulle, E. (Ed.) (2004). Old Age and Agency, New York: Nova Science Publishers.

van Oorschot, W. \& Jensen, P.H. (2009). Early retirement differences between Denmark and The Netherlands: A cross-national comparison of push and pull factors in two small European welfare states, Journal of Aging Studies 23(4): 267-278. doi: http://dx.doi.org/10.1016/j. jaging.2008.01.003.

Vickerstaff, S. (2006). 'I'd rather keep running to the end and then jump off the cliff'. Retirement decisions: who decides? Journal of Social Policy 35(3): 455-427. doi: http://dx.doi. org/10.1017/S0047279406009871. 